\title{
堆肥化とバイオガス化による牛ふん尿の臭気の 低減効果の検討
}

\author{
谷川昇, 古市 徹, 石井一英, 西上 耕平
}

\begin{abstract}
固形物などの臭気試料を簡便に調製する方法を提案するとともに，その方法を用いて牛ふん尿および牛ふ ん尿の堆肥化物とバイオガス化液状残渣（液肥）の臭気指数を測定した.

牛ふん尿の臭気ポテンシャル*は24 35 と幅広い值であった. 牛ふん尿の堆肥化物と液肥の臭気ポテン シャル（Y）は，牛ふん尿の臭気ポテンシャル（X) より 3〜11 低い 20〜25の值であり，堆肥化とバイオガ ス化による牛ふん尿の臭気低減効果を定量的に示すことができた。
\end{abstract}

\section{1. 緒言}

家畜ふん尿の排出量の産業廃棄物総排出量に占める割 合は，日本全国では約 $23 \% 11$ ，北海道のように畜産農業 が盛んな地域では $50 \%$ を超えて ${ }^{2)}$ おり，その適正処理と 有効利用が強く求められている。これまで, 家畜ふん尿 は, 飼料作物や農産物の生産に有効利用してきたとされ ている ${ }^{3)}$.しかし，実際には，家畜ふん尿を直接散布す る，家畜ふんを圃場に積み上げる，尿を素掘りのピット にためるなどの不適正な処分む行われてきた。 そのた め，家畜ふん尿の保管や利用にあたっての悪臭苦情4),5) の発生や有機性污濁物質, 硝酸態窒素, 病原性大腸菌群 類などの流出による地下水污染，周辺流域の水質污濁問 題などが指摘されている ${ }^{6)}$.

このような家畜ふん尿に起因する環境問題発生の未然 防止と家畜ふん尿の一層の有効利用促進を目的として, 平成 16 年 11 月から家畜排せつ物法が完全施行され, 一 定規模の畜産農家に対して屋根と側壁のある不浸透性材 料の床材を使用した施設での家畜ふん尿管理などが義務 付けられるとともに, 家畜ふん尿の堆肥化施設やバイオ ガス化施設の導入が図られている。これらの施設から得 られる堆肥化物や液肥として利用できるバイオガス化液 状残渣（以下液肥と記す）の臭気は，むとの家畜ふん尿 に比べて低減されることが経験上知られている ${ }^{7) \sim 9)}$. 総 悪臭苦情件数の約 $10 \%$ を占める畜産農業からの悪臭苦 情4) を減少させるためにも，家畜ふん尿の堆肥化やバイ オガス化による臭気低減効果を嗅覚測定法によって定量 的に示して畜産農家に周知し，これらの技術導入の動機 付けの一つとすることが必要である。ただし，これまで
は，固形物またはスラリー状物（以下固形物などと記す） の臭気を測定するための臭気試料調製方法が標準化され ていないこともあり，堆肥化物の臭気指数測定例がわず かに報告されている ${ }^{10)}$ あの，嗅覚測定法によって家畜 ふん尿とその堆肥化物や液肥の臭気を系統的に調べた報 告はない.

そこで, 本研究では, 固形物などの臭気試料の簡便な調 製方法を提案するとともに，その方法を用いて家畜ふん尿 排出量の多くを占める ${ }^{3)}$ 牛ふん尿および牛ふん尿の堆肥化 物と液肥の臭気指数を測定し, 堆肥化とバイオガス化によ る牛ふん尿臭気の低減効果を定量的に明らかにした。

\section{2. 実験}

\section{1 固形物などの簡便な臭気試料調製方法の検討}

家畜ふん尿や堆肥化物，液肥のような固形物などの簡 便な臭気試料調製方法（以下簡便法と記す）として，以 下の方法を提案した。

（1）固形物などを $1 \mathrm{~L}$ のポリエチレン製広口びん（以 下ポリビンと記す）に採取し，密栓して実験室に 持ち帰る。

（2）固形物などが入ったポリビンを $45 \mathrm{~L}$ ポリエチレ ン製袋内に置き，キャップをはずす。

（3）図ー1 に示すように，ポリエチレン製袋入口を密 閉し, 活性炭で処理した約 $30 \mathrm{~L}$ の無臭空気をテ フロン管より袋内に導入し，コックを閉じる.

（4）一定時間静置した後のポリエチレン製袋内の空気 をポンプによって $10 \mathrm{~L}$ ポリエステル製袋に移し, 臭気試料とする。

本簡便法において，固形物などからの臭気成分が密閉

谷川 昇 (たにかわ のぼる), 古市 徹 (ふるいち とおる), 石井 一英 (いしい かずえい), 西上 耕平 (にしがみ こうへい) 北海道大学大学院工学研究科 $\overline{\mathbf{T}} 060-8628$ 北海道札幌市北区北 13 西 8 *簡便法によって調整した臭気試料の臭気指数を「臭気ポテンシャル」とした。 


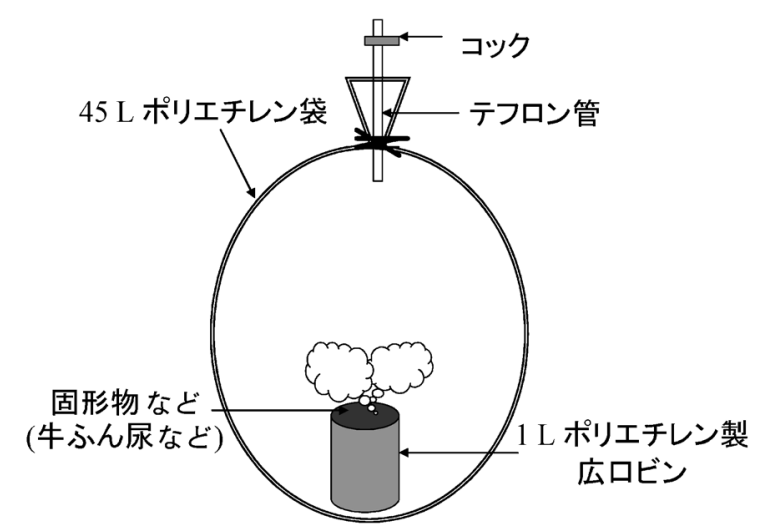

図-1 固形物などの臭気試料の簡便な調製方法

したポリエチレン製袋内の無臭空気と平衡状態になるま でに必要な静置時間を確認するために, 約 $20^{\circ} \mathrm{C}$ の実験 室で，牛ふん尿が入ったポリビンをポリエチレン製袋内 に 3, 6, 12 時間静置した時の臭気試料の臭気指数を三点 比較式臭袋法で計測した。

\section{2 牛ふん尿の堆肥化とバイオガス化による臭気低減 効果の検討}

牛ふん尿の堆肥化とバイオガス化による臭気低減効果 を検討するために，2004 年 11 月から 2005 年 9 月の間 に, 北海道内の畜産農家の牛舎と表 -1 , 表 -2 に示す堆 肥化施設とバイオガス化施設から牛ふん尿, 堆肥化物ま たは液肥を採取した。 $\mathrm{A}$ 施設と $\mathrm{B}$ 施設は，牛ふん尿と水 分調整材の混合物を 1 日に数回自動的に切り返しを行っ ている（以下自動擋拌方式と記す）堆肥化施設である. $\mathrm{A}$ 施設では, 約 20 軒の畜産農家が一時保管している牛 ふん尿を約 2 週間周期で戸別に収集して建屋内で堆肥化 しており, B 施設では B 畜産農家が自ら排出する牛ふん 尿を建屋内で堆肥化している。 C 施設では，C畜産農家 が屋根と側壁のある不浸透性材料の床材を使用した堆肥 舎において，牛ふん尿と水分調整材の混合物を 2 週間に 一回程度重機による切り返し（以下重機切り返し方式と 記す）を行って，堆肥を製造している.

$\mathrm{D}$ 施設と $\mathrm{E}$ 施設のバイオガス化施設では，D畜産農家 と $\mathrm{E}$ 畜産農家が自ら排出する牛ふん尿を嫌気的雰囲気 のメタン発酵槽内で微生物分解し，メタンを主成分とす るバイオガスを回収して発電機の燃料として利用すると ともに，メタン発酵槽で生じる液肥を牧草地などに散布 する時期まで貯留設備に長期間保管している。 D 施設は メ夕ン発酵槽内温度を約 $55^{\circ} \mathrm{C}$ に保つ高温発酵方式を， $\mathrm{E}$ 施設はメ夕ン発酵槽内温度を約 $37^{\circ} \mathrm{C}$ に保つ中温発酵方 式を採用している。

採取した牛ふん尿，堆肥化物および液肥の臭気試料を 簡便法で調製し，それらの臭気指数を三点比較式臭袋法
表 -1 調査対象堆肥化施設の概要

\begin{tabular}{|c|c|c|c|}
\hline 施設 & A 施設 & B 施設 & $\mathrm{C}$ 施設 \\
\hline 処理対象 & 乳牛ふん尿など & 乳牛ふん尿 & 乳牛ふん尿 \\
\hline 処理量 & $26 \mathrm{t} /$ 日 & $15 \mathrm{~m}^{3}$ /日 & 30 t/180 日 \\
\hline 方式 & $\begin{array}{l}\text { 開放型自動口- } \\
\text { 少-擋拌(自 } \\
\text { 動擋汼方式) }\end{array}$ & $\begin{array}{l}\text { 開放型自動口- } \\
\text { 年-擋拌(自 } \\
\text { 動擋拌方式) }\end{array}$ & $\begin{array}{l}\text { 重機による切 } \\
\text { り返し(重機切 } \\
\text { り返し方式) }\end{array}$ \\
\hline 水分調整材 & 木材チップ & あみがら & 剪定枝チップ \\
\hline 処理日数 & 33 日 (1 次発酵) & 20 日（1 次発酵） & 18 日 \\
\hline
\end{tabular}

表－2＼cjkstart調查対象バイオガス化施設の概要

\begin{tabular}{c|c|c}
\hline 施設 & $\mathrm{D}$ 施設 & $\mathrm{E}$ 施設 \\
\hline 処理対象 & 乳牛ふん尿 & 乳牛ふん尿 \\
\hline 処理量 & $25 \mathrm{t} /$ 日 & $15 \mathrm{~m}^{3} /$ 日 \\
\hline 発酵方式 & 高温発酵 $\left(55^{\circ} \mathrm{C}\right)$ & 中温発酵 $\left(37^{\circ} \mathrm{C}\right)$ \\
\hline 処理日数 & 15 日 & 15 日 \\
\hline バイオガス利用 & 発電・温水 & 発電・温水 \\
\hline
\end{tabular}

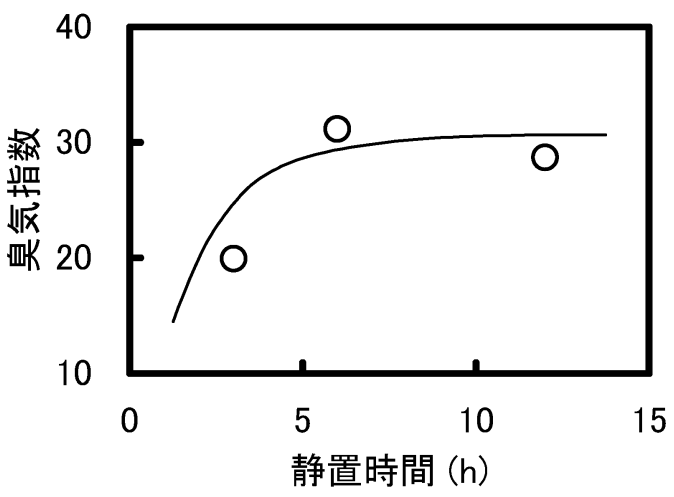

図－2＼cjkstart簡便法の静置時間と臭気指数との関係

によって測定した。また，5畜産農家の牛舎内空気を採 取して，その臭気指数も三点比較式臭袋法によって測定 し，簡便法によって調製した牛ふん尿臭気の臭気指数と 比較した。

\section{3. 結果および考察}

\section{1 固形物などの臭気試料調製方法の検討}

簡便法による静置時間を $3,6,12$ 時間とした牛ふん尿 の臭気指数の測定結果を図 -2 に示す. 静置時間が 12 時 間の臭気指数は，6時間の臭気指数よりわずかに低く なっていたが，牛ふん尿をポリエチレン製袋内で約 6 時 間以上静置すれば，牛ふん尿に含まれる臭気成分と平衡 状態となった臭気試料が得られると推定された。なお， ポリエチレン製袋内に固形物などを入れずに無臭空気を 
封入後 12 時間放置して調製したブランク臭気試料の臭 気濃度は 13 であり，簡易法による牛ふん尿臭気の臭気 指数の測定にあたって，ポリエチレン製袋の固有臭気は 無視できることを確認した.

そこで, 以降の実験では, 約 $20^{\circ} \mathrm{C}$ の室内において静置 時間を 6 時間以上確保して簡便法で調製した牛ふん尿, 堆肥化物および液肥の臭気試料の臭気指数を測定した。 簡便法によって調製した臭気試料の臭気指数は，固形物 などの試料が潜在的に有する臭気の最大レベルと考えら れ，以下では臭気ポテンシャルとした。

\section{2 牛ふん尿の堆肥化とバイオガス化による臭気低減 効果の検討}

\subsection{1 牛ふん尿の臭気ポテンシャル}

採取した牛ふん尿の臭気ポテンシャルと牛舎内空気の 臭気指数の測定結果を表一3に示す。牛ふん尿の臭気ポ テンシャルは, 24〜35 と幅広い值であり, $\mathrm{A}$ 施設の牛子 几尿の臭気ポテンシャルは, 24 と他の牛ふん尿之比べて 特に小さかった。この原因は，A 施設の家畜ふん尿は， 畜産農家で最長 2 週間程度保管されており, 保管中に臭 気成分が一部揮散しているためと推定できる。

牛ふん尿が腐敗し易い気温が高い季節には，牛ふん尿 の臭気ポテンシャルが高くなる可能性が考えられる。し かし, 気温が高い時期に採取した牛ふん尿の臭気ポテン シャルが特に大きいわけではないこと，D畜産農家にお いて 2 月と 11 月に採取した牛ふん尿の臭気ポテンシャ ルの差はわずかであることから，牛ふん尿の臭気ポテン シャルには，季節变動の影響は明確には現れていなかっ た。したがって, 臭気ポテンシャルの变動幅は, 季節変
動より屯各畜産農家における飼料の違いなどに起因して いると推定される.

表-3 に示す畜産農家の牛舎内空気の臭気指数は，報 告例 ${ }^{11), 12)}$ と同程度であるものの，11～20 と差がみられ た。牛舎内空気の臭気は，牛ふん尿の臭気と牛舎の密閉 性の影響を受けると考えられるが，密閉した牛舎内空気 の臭気指数とみなせる牛ふん尿の臭気ポテンシャルは, 29〜32 と大きな違いがなかった. したがって, 牛舎内空 気の臭気指数に差がみられたのは，牛舎の密閉性が異な るためと推定される。

\section{2.2 牛ふん尿の堆肥化とバイオガス化による臭気 低減効果}

堆肥化施設とバイオガス化施設における処理対象牛ふ ん尿, 堆肥化物および液肥の臭気ポテンシャルの測定結 果を表一 4 に示す。自動擋拌方式の A, B 施設の堆肥化 物と重機切り返し方式の $\mathrm{C}$ 施設の堆肥化物の臭気ポテ ンシャルは同程度であり, 堆肥化物の臭気ポテンシャル には堆肥化方式の違いによる差はみられていなかった。 また，D施設で異なる時期 ( 2 月と 9 月) に採取した液肥 の臭気ポテンシャルは同じ值が得られていること, D 施 設と $\mathrm{E}$ 施設の液肥の臭気ポテンシャルはほとんど变わ らないことから, 液肥の臭気ポテンシャルの变動は小さ いと推定された。

堆肥化物と液肥からは牛ふん尿臭は感じられず，それ らの臭気ポテンシャルは，牛ふん尿の臭気ポテンシャル より 3〜11 低い 20〜25の值であり, 堆肥化とバイオガ ス化による牛ふん尿の臭気低減効果を定量的に示すこと ができた。堆肥化物または液肥の臭気ポテンシャルと牛 ふん尿の臭気ポテンシャルとの関係を図ー3に示す。㛜

表 -3 牛ふん尿の臭気ポテンシャルと牛舎内の臭気指数の測定結果

\begin{tabular}{l|c|c|c|c|c|c|c|c|c}
\hline 採取場所 & $\mathrm{A}$ 施設 & $\mathrm{B}$ 農家 & $\mathrm{C}$ 農家 & \multicolumn{2}{|c|}{$\mathrm{D}$ 農家 } & $\mathrm{E}$ 農家 & $\mathrm{F}$ 農家 & $\mathrm{G}$ 農家 & $\mathrm{H}$ 農家 \\
\hline 飼養牛種 & 乳牛・肉牛 & 乳牛 & 乳牛 & \multicolumn{2}{|c|}{ 乳牛 } & 乳牛 & 乳牛 & 乳牛 & 乳牛 \\
\hline 採取月 & 2 月 & 9 月 & 1月 & 2 月 & 11 月 & 6 月 & 11 月 & 11 月 & 11 月 \\
\hline 牛ふん尿の臭気ポテンシャル & 24 & 29 & 29 & 35 & 32 & 34 & 30 & 30 & 32 \\
\hline 牛舎内空気の臭気指数 & & & 20 & & 20 & & 11 & 19 & 12 \\
\hline
\end{tabular}

表－4 堆肥化施設とバイオガス化施設における臭気ポテンシャルの測定結果

\begin{tabular}{l|c|c|c|c|c|c}
\hline \multirow{2}{*}{ 施設 } & \multicolumn{3}{c|}{ 堆肥化施設 } & \multicolumn{3}{c}{ バイオガス化施設 } \\
\cline { 2 - 7 } & $\mathrm{A}$ 施設 & $\mathrm{B}$ 施設 & $\mathrm{C}$ 施設 & \multicolumn{2}{|c|}{$\mathrm{D}$ 施設 } & $\mathrm{E}$ 施設 \\
\hline 処理対象牛ふん尿 & 24 & 29 & 29 & 35 & 32 & 34 \\
\hline 堆肥化物 & 21 & 21 & 20 & & & \\
\hline 液肥 & & & & 24 & 24 & 25 \\
\hline
\end{tabular}




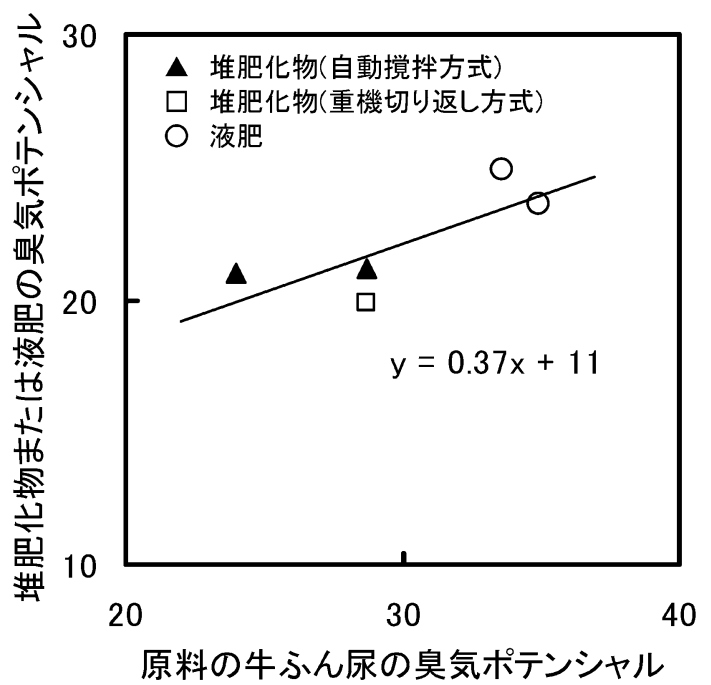

図-3 堆肥化物と液肥の臭気ポテンシャルと牛ふん尿 の臭気ポテンシャルとの関係

密には同列で比較できないが，堆肥化物または液肥の臭 気ポテンシャル $(\mathrm{Y})$ と牛ふ九尿の臭気ポテンシャル （X）との関係は，実験の範囲では見かけ上(1)式で近似 的に示された。

$$
\mathrm{Y}=0.37 \mathrm{X}+11
$$

なお, 堆肥化物の臭気ポテンシャルは, 液肥の臭気ポテ ンシャルよりやや小さくなる結果が得られている。その 第一の理由としては, バイオガス化プロセスは密閉型で あり，臭気成分はバイオガスと液肥に移行するのに対し て, 開放系で行われる堆肥化プロセスでは, 好気性発酵を 促進させるための牛ふん尿の切り返しや通風によって臭 気成分が長期間にわたって環境中に揮散すると考えられ ること, 第二の理由としては, 堆肥化施設の原料の牛ふん 尿の臭気ポテンシャルがバイオガス化施設の牛ふん尿の 臭気ポテンシャルより小さかったことが挙げられる.

\section{4. 結論}

固形物などの臭気試料を簡便に調製する方法を提案す るととあに，その方法を用いて牛ふん尿求よび牛ふん尿 の堆肥化物とバイオガス化液状残渣（液肥）の臭気指数 （臭気ポテンシャル）を測定したところ, 次の結果が得ら れた。

（1）牛ふん尿の臭気ポテンシャルは 24〜35 と幅広い
值であった．また，牛舎内空気の臭気指数は，牛 ふん尿の臭気ポテンシャルより 9 20 低い值で あった。

（2）堆肥化物之液肥の臭気ポテンシャルは，牛ふん尿 の臭気ポテンシャルょり 3〜11 低い 20〜25 の值 であり，堆肥化とバイオガス化による牛ふん尿の 臭気低減効果を定量的に示すことができた。

（3）堆肥化物または液肥の臭気ポテンシャル（Y) と 牛ふん尿の臭気ポテンシャル $(\mathrm{X})$ との関係は，見 かけ上 $\mathrm{Y}=0.37 \mathrm{X}+11$ で近似された。

キーワード : 臭気指数, 牛ふん尿, 堆肥化, バイオガス化

\section{参考文献}

1 ）環境省大臣官房廃棄物・リサイクル対策部循環型社会推 進室 : (2005), “循環型社会白書 (平成 17 年版)”, p 63.

2 ) 北海道環境生活部環境室循環型社会推進課: (2005), “北 海道循環型社会推進基本計画”, p 16 .

3 ) 古市徹監修 ORS 研究会編著：(2001), “有機系廃棄物の リサイクル戦略”, p 15，環境産業新聞社.

4 ）環境省水・大気環境局大気生活環境室：(2005), “平成 16 年度悪臭防止法施行状況調査について”。

5 ）農林水産省生産局畜産部畜産企画課畜産環境対策室: （2006），“畜産経営に起因する苦情発生状況”。

6 ）北海道立農業・畜産試験場家畜ふん尿プロジェクト研究 チーム：(2005), “環境に配慮した畜産農場経営を目指し て”，p 5-7，北海道立農業・畜産試験場.

7 ) 松田従三: 家畜ふん尿用バイオガスプラントの実態と課 題, エネルギー利用システム, 8, 追録第 23 号, 423-428の 8, (2004)

8 ）清水心太, 古市 徹, 谷川 昇, 石井一英 : アンケート調 査による畜産農家の家畜ふん尿処理実態の把握, 第 16 回 廃棄物学会研究発表会講演論文集, 727-729，（2005）。

9）梅津一孝：(2003), 寒冷地における高温バイオガスプラ ントの稼働状況, “欧州諸国における循環型農業の発展之 バイオエネルギー市場の形成に関する比較研究一平成 12 年度 平成 14 年度科学研究費補助金（基盤研究（B）（2） 研究成果報告書”, p 74 .

10）山本朱美，喜多純一，小川雄比古，小堤恭平，古谷 修： におい識別装置による畜舎および堆肥臭気の強度評価, に おい・か㧍り環境学会誌，37，33-37，(2006).

11）環境庁大気保全局特殊公害課：(1982), “昭和 56 年度官 能試験法調査報告書”, p 46-47.

12）環境省環境管理局：(2001), “臭気指数規制ガイドライン 参考資料”, p 31 . 


\title{
Study of reduction of odor from cow excreta by composting and biogasification
}

\author{
Noboru TANIKAWA, Toru FURUICHI, Kazuei ISHII, Kohei NISHIGAMI \\ Graduate School of Engineering, Hokkaido University, \\ N13 W8, Kita-ku, Sapporo, Hokkaido
}

\begin{abstract}
We propose a convenient method of preparing samples of solid and slurry materials for odor measurement. Odor indices of cow excreta, compost, and liquid residue (liquid manure) sampled from cow barns and also from composting and biogasification facilities treating cow excreta were measured by the triangle odor bag method after preparation using our method.

The odor indices $(\mathrm{X})$ of cow excreta were in the range 24-35. The odor indices of compost and liquid manure (Y) were about 20-25, lower than the odor indices of cow excreta. The differences of the odor indices were in the range 3-11. By this method, the degree of reduction in odor by composting and biogasification of cow excreta was shown quantitatively.
\end{abstract}

Key words : odor index, cow excreta, composting, biogasification

(受稿 平成 18 年 4 月 24 日)

（受理 平成 18 年 10 月 23 日） 